\title{
Characterization of Lakhodair Landfill Leachate
}

\author{
Madeeha Saleem*, Isbah Hameed and Saifur Rehman Kashif
}

Department of Environmental Sciences, Faculty of Bio Sciences, University of Veterinary and Animal Sciences, Lahore, Pakistan

*Corresponding author: Madeeha Saleem, Department of Environmental Sciences, Faculty of Bio Sciences, University of Veterinary and Animal Sciences, Lahore, Pakistan, Tel: +923217815579; E-mail: madeehasaleem1395@yahoo.com

Received date: October 12, 2017; Accepted date: October 28, 2017; Published date: October 31, 2017

Copyright: (c) 2017 Saleem M, et al. This is an open-access article distributed under the terms of the Creative Commons Attribution License, which permits unrestricted use, distribution, and reproduction in any medium, provided the original author and source are credited.

\begin{abstract}
Leachate is the water contained in the solid waste dumped in a landfill and comes out during its decomposition but continues to ooze out even after stabilization of the solid waste and many years after the closure of the landfill. It contains a number of toxic and hazardous compounds, and is likely to contaminate the environmental sinks. Moreover, this leachate varies in its flows and characteristics over different phases of a landfill life. Leachate management is one of the major concerns and tough task associated with the landfill operation, and comprises monitoring and predicting landfill leachate and the variation in its flows and composition, associated risk assessment and hazard rating, and designing the most accurate treatment system before disposing it into environmental sinks. This study has analyzed the characteristics of a newly designed landfill site on modern lines at Lakhodair, Lahore, finding it to be slightly alkaline and high in organic matter $\left(\mathrm{BOD}_{5}, \mathrm{COD}\right), \mathrm{Na}, \mathrm{K}$ and a few heavy metals (Ni and $\mathrm{Cr}$ ) of the sixteen pollution indicators (EC, turbidity, hardness, TDS, TSS, $\mathrm{BOD}_{5}, \mathrm{COD}, \mathrm{Na}, \mathrm{K}, \mathrm{Cl}, \mathrm{Ni}, \mathrm{Cr}, \mathrm{Pb}, \mathrm{Mn}, \mathrm{Cu}, \mathrm{Zn}$ ), which indicates it can easily be treated with simple physic-chemical methods; such as coagulation/flocculation, sedimentation, filtration, and biological treatment, and brought into some reuse such as irrigation.
\end{abstract}

Keywords: Leachate; Organic matter; Liquor; Inorganic pollutants

\section{Introduction}

Landfills nowadays are very important and essential for the accumulation or storage of solid waste [1]. Rather, these are globally considered the best option for managing municipal solid waste $[2,3]$ and have maintained their status of the eventual fortune for all types of solid waste [4]. Further, this is the cheapest way for the disposal of large amount of waste [5] and is hence a common practice in most of the countries across the globe [6].

Leachate is the liquor that oozes out of the solid waste dumped in a landfill during its decomposition $[7,8]$ and even after hundreds of years of the landfill closure [9]. This leachate varies in its flows and characteristics at different phases of a landfill life cycle $[1-3,9,10]$ and along different seasons $[1,10]$.

Leachate is a source of soil and groundwater contamination, due to the high nitrogen loading and likelihood of high degree of toxicants present $[9,11,12]$. Strong negative correlation established between the distance from the landfill site and the contaminant loading in the soil and water has confirmed the pollutants to be concentrated at the source or point of generation [13].

Monitoring and predicting landfill leachate and the variation in its flows and composition, associated risk assessment and hazard rating, and designing the most accurate treatment system before disposing it into environmental sinks are the phases of leachate management required to protect environment and the human beings from its harmful impacts $[3,13]$.

Leachate needs to be characterized in order to have an estimate of contamination at the area [1]. Characterization is done in terms of appearance, odor, $\mathrm{pH}$, Dissolved Oxygen (DO), Total Suspended Solids (TSS), Total Dissolved Solids (TDS), Turbidity, Hardness, Biological
Oxygen Demand $\left(\mathrm{BOD}_{5}\right)$, Chemical Oxygen Demand (COD), $\mathrm{BOD}_{5} / \mathrm{COD}$ ratio, Chloride content $\left(\mathrm{Cl}^{-1}\right)$, Nitrate $\left(\mathrm{NO}_{3}{ }^{-1}\right)$, ammonium nitrogen $\left(\mathrm{NH}_{3}-\mathrm{N}\right)$, Total Kjeldahl Nitrogen (TKN), Total Phosphorus $(\mathrm{P})$, and Sulfate $\left(\mathrm{SO}_{4}^{-2}\right)$ loading $[2,14]$.

In Lahore, from different dumping sites different parameters were determined such as $\mathrm{pH}$ from 5.5 to $8.7, \mathrm{DO} 2.1$ to $2.7 \mathrm{mg} / \mathrm{L}$. Turbidity between 32.5 and $73.0 \mathrm{NTU}$, TSS value of $161-500 \mathrm{mg} / \mathrm{L}$, TDS $3717-3500 \mathrm{mg} / \mathrm{L}, \mathrm{BOD}_{5}$ in the range $442-10,000 \mathrm{mg} / \mathrm{L}$, COD ranging from $1925-18,000 \mathrm{mg} / \mathrm{L}$ and $\mathrm{BOD}_{5} / \mathrm{COD}$ ratio of 0.45 to 0.82 . The concentration of Sulfates, Phosphates, Nitrates, Chlorides and Total Nitrogen were 55.5-83.7 mg/L, 78.5-84.7 mg/L, 48.0-65.8 mg/L, 232-312 mg/L and $400 \mathrm{mg} / \mathrm{L}$, respectively. Heavy metals $(\mathrm{Fe}, \mathrm{Cu}, \mathrm{Pb}$, As) were detected in the range of 0.60 to $9.80 \mathrm{mg} / \mathrm{L}[1,2,15,16]$.

\section{Materials and Methods}

The study methodology comprised leachate sample from the Lakhodair landfill site, sample preservation and transportation, laboratory assessment and descriptive statistical analysis. Leachate sample was collected in a $1 \mathrm{~L}$ plastic bottle washed with hot water, nitric acid, tap water and three times with distilled water from the pond receiving the leachate from the drainage pipes underlying the cover of the Lakhodair landfill site; the modern sanitary landfill site newly constructed in Lahore with a covered area of 28 ha and a total area $53 \mathrm{ha}$, with the remaining area reserved for future extension as may be required. Landfill comprises of 6 plots, of which 2 have yet come into operation since 18 April, 2016. 2000-2500 tpd of waste is being dumped in the working plots of this landfill. After collection, these samples were transported to the laboratory for analysis in ice chests and preserved at $4^{\circ} \mathrm{C}$ till analysis. APHA described standard methods were followed for all the tests selected to indicate the quality and characteristics of the leachate. $\mathrm{pH}$ meter (HI 2210) was first calibrated with distilled water and the buffer in the alkaline range, and used to measure $\mathrm{pH}$ of the sample. Calibrated EC meter (HI 8633) was 
Page 2 of 3

used to get EC of the leachate. Turbidity of the sample was assessed with turbidity meter (ExTech TB400). Flame photometer (BiotechEngineering AFP-100) was used to calculate Potassium and Sodium concentration in the leachate. Heavy metals ( $\mathrm{Ni}, \mathrm{Fe}, \mathrm{Zn}, \mathrm{Cr}, \mathrm{Pb}, \mathrm{Mg}$, $\mathrm{Cu}, \mathrm{Mn}$ ) were evaluated with Atomic Absorption Spectrophotometer (AAS) (Hitachi Z-8230). Total dissolved solids (TDS) and Total Suspended Solids (TSS) were checked gravimetrically. Biological Oxygen Demand (BOD) was observed with BOD incubator (SAYO MIR-153). Chemical Oxygen Demand (COD), hardness and chloride concentration were determined via titration.

\section{Results and Discussion}

Results of sixteen quality parameters besides $\mathrm{pH}$, indicating pollution load of the leachate collected from Lakhodair landfill side; a modern sanitary landfill side newly designed in Lahore are summarized in Table 1 given below. Values for the parameters whose tolerable level have been established in Punjab Environmental Quality Standards (PEQS) have also been compared with those standard value in the underlying table.

\begin{tabular}{|c|c|c|c|c|c|c|c|c|c|c|c|c|c|c|c|c|c|}
\hline $\begin{array}{l}\text { Treatme } \\
\text { nts }\end{array}$ & $\mathrm{pH}$ & $\begin{array}{l}\mathrm{EC} \\
\mathrm{ms} / \mathrm{cm}\end{array}$ & $\begin{array}{l}\text { Turbid } \\
\text { ity }\end{array}$ & $\begin{array}{l}\mathrm{TDS} \\
\mathrm{mg} / \mathrm{L}\end{array}$ & $\begin{array}{l}\mathrm{TSS} \\
\mathrm{mg} / \mathrm{L}\end{array}$ & $\begin{array}{l}\text { Hardness } \\
\mathrm{mg} / \mathrm{L}\end{array}$ & $\begin{array}{l}\text { BOD5(m } \\
\text { g/L) }\end{array}$ & $\begin{array}{l}\text { COD } \\
\mathrm{mg} / \mathrm{L}\end{array}$ & $\begin{array}{l}\mathrm{Cl}-1 \\
\mathrm{mg} / \mathrm{L}\end{array}$ & $\begin{array}{l}\mathrm{Na} \\
\text { (ppm) }\end{array}$ & $\begin{array}{l}K \\
(\mathrm{ppm} \\
)^{2}\end{array}$ & $\begin{array}{l}\mathrm{Ni} \\
(\mathrm{ppm})\end{array}$ & $\begin{array}{l}\mathrm{Cr} \\
\text { (ppm) }\end{array}$ & $\begin{array}{l}\mathrm{Pb} \\
(\mathrm{ppm})\end{array}$ & $\begin{array}{l}\text { Mn } \\
\text { (ppm } \\
)^{2}\end{array}$ & $\begin{array}{l}\text { Cu } \\
\text { (ppm } \\
\text { ) }\end{array}$ & $\begin{array}{l}\mathrm{Zn} \\
\text { (ppm } \\
)^{2}\end{array}$ \\
\hline $\begin{array}{l}\text { Leachat } \\
\text { e }\end{array}$ & 8.43 & 30 & 102 & 8000 & 4500 & 1000 & 724 & 1701 & 1980 & 4150 & 4670 & 1.78 & 1.54 & 0.35 & 0.82 & 0.06 & 0.02 \\
\hline PEQS & $\begin{array}{l}06-09-2 \\
017\end{array}$ & - & - & 3500 & 400 & - & - & 400 & 1000 & - & - & 1 & - & 0.5 & 1.5 & 1 & 5 \\
\hline
\end{tabular}

Table 1: Leachate parameters readings before and after treatment.

Solid waste dumped at a landfill site undergoes four phases of degradation characterized by aerobic, acidogenic and methanogenic degradation phases followed by stabilization. Leachate generated in the four phases differs significantly in its composition and quantity; initially being high in degradable organic matter and soluble metal salts, and in non-biodegradable inorganic pollutants in later stages [14]. Since, leachate was collected from Lakhodair landfill site within six months of its inauguration; it was assumed that the leachate could be characterized to experience the aerobic degradation phase. Most of the characteristics confirmed this assumption. As expected, the leachate was high in $\mathrm{BOD}_{5}, \mathrm{COD}$, Sodium, Potassium sand a few heavy metals; especially Ni and Cr. Chromium comes into the leachate from paint products and wood preservatives that get added into the municipal solid waste and nickel is added from used batteries [1]. Landfill site is not old enough and not yet undergone acidogenic phase of degradation so the leachate is slightly alkaline; i.e., 8.43. The heavy metals that had low concentrations; i.e., $\mathrm{Mn}, \mathrm{Zn}, \mathrm{Fe}, \mathrm{Cu}$ and $\mathrm{Pb}$ were those having low solubility in water at alkaline $\mathrm{pH}[1,17]$. Processes like sorption and precipitation also cause reduction in the amount of these heavy metals in leachate [17]. $\mathrm{BOD}_{5} / \mathrm{COD}$ ration was, however, surprisingly lower than expected as per literature but in agreement with the value obtained by Kulimowska and Klimiuk [18]. High organic and inorganic solids contributed to high TDS and TSS concentration and the metal salts to high EC. Besides these constituents, Lakhodair landfill leachate was also found to be high in hardness, turbidity and chlorides.

\section{Conclusions and Recommendations}

Results for the pollutant loading in the Lakhodair landfill leachate have confirmed that the landfill is rightly claimed to be modern and sanitary in its design. The pollutant load aligns with the pollutant loading of similar landfill sites around the world, as found in the literature. The leachate was found to be non-toxic; especially in regards to the heavy metal contamination since their concentration was within the limits as specified by the Punjab Environmental Quality Standards (PEQS), except nickel. Other parameters; like BOD, TDS. TSS, chlorides, however, exceeded their prescribed values. But since, as expected in its early stage of operation when the waste is experiencing aerobic phase of degradation, and has not yet undergone acidic or fermented decomposition, the leachate is rich in organic contaminants, and is hence suitable for reuses as in irrigation of crops other than food crops, or which are to be used after some processing, or for landscape irrigation, in flushing systems, or in industrial systems, after some primary and/or secondary level of treatment, provided the organic compounds are not persistent. After this study, the organics in the leachate need to be characterized and checked for their persistence, Lakhodair landfill leachate needs to be optimized for various treatment options and brought to some economical reuse. Since the leachate did not match municipal sewage in its characteristics, its combined treatment with domestic wastewater in an ordinary Sewage Treatment Plant (STP) is not suggested. Economical and easy-to-handle treatments such as coagulation/flocculation, sedimentation, floatation, activated sludge process, aerated lagoons are best recommended.

\section{References}

1. Munir S, Tabinda AB, Ilyas A, Mushtaq T (2014) Characterization of Leachate and Leachate Pollution Index from Dumping Sites in Lahore, Pakistan. J Appl Environ Biol Sci 4: 165-170.

2. Raman N, Narayanan DS (2008) Impact of solid waste effect on ground water and soil quality nearer to pallavaram solid waste landfill site in Chennai. Rasayan J Chem 1: 828-836.

3. Mukherjee S, Mukhopadhyay S, Hashim MA, Gupta BS (2015) Contemporary Environmental Issues of Landfill Leachate: Assessment and Remedies. Critical Reviews Environ Sci Techno 45: 472-590.

4. Gbanie SP, Tengbe PB, Momoh JS, Medo J, Kabba VTS (2013) Modelling landfill location using geographic information systems (GIS) and multicriteria decision analysis (MCDA): case study Bo, Southern Sierra Leone. Appl Geography 36: 3-12.

5. Frascari D, Bronzini F, Giordano G, Tedioli G, Nocentini M (2004) Longterm characterization, lagoon treatment and migration potential of landfill leachate: A case study in an active Italian landfill. Chemos 54: 335-343.

6. Samadi MT, Saghi MH, Rahmani A, Hasanvand J, Rahimi S, et al. (2010) Hamadan landfill leachate treatment by coagulation - flocculation process. Iran J Environ Health Engg 7: 253.

7. Tyrrel SF, Leeds-Harrison PB, Harrison KS (2002) Removal of ammoniacal nitrogen from landfill leachate by irrigation onto vegetated treatment planes. Water Res 36: 291-299. 
Citation: Saleem M, Hameed I, Kashif SR (2017) Characterization of Lakhodair Landfill Leachate. J Environ Anal Chem 4: 219. doi: 10.4172/2380-2391.1000219

Page 3 of 3

8. Zainol NA, Aziz HA, Yusoff MS, Umar M (2011) The use of Polyaluminum Chloride for the treatment of Landfill Leachate via Coagulation and Flocculation processes. Res J Chem Sci 1: 34-39.

9. Jones DL, Williamson KL, Owen AG (2006) Phytoremediation of landfill leachate. Waste Manag 26: 825-837.

10. Esakku S, Karthikeyan OP, Joseph K, Nagendran R, Palanivelu K, et al. (2007) Seasonal Variations in Leachate Characteristics from Municipa Solid Waste Dumpsites in India and Srilanka. Proceed Inter Con Sus Solid Waste Manag, pp. 341-347.

11. Justin MZ, Zupancic M (2009) Combined purification and reuse of landfill leachate by constructed wetland and irrigation of grass and willows. Desalination 2461: 157-168.

12. Bashir MJK, Xian TM, Shehzad A, Sethupahi S, Aun NC, et al. (2017) Sequential treatment for landfill leachate by applying coagulationadsorption process. Geosystem Engg 20: 9-20.

13. Salem Z, Hamouri K, Djemaa R, Allia K (2008) Evaluation of Landfill Leachate Pollution and Treatment. Desalination 220: 108-114.
14. Bhalla B, Saini MS, Jha MK (2012) Characterization of leachate from Municipal Solid Waste (MSW) Landfilling Sites of Ludhiana, India: A Comparative Study. Int J Engg Res Appli 2: 732-745.

15. Kjeldsen P, Barlaz MA, Rooker AP, Baun A, Ledin A, et al. (2002) Present and Long-Term Composition of MSW Landfill Leachate: A Review. Critical Reviews Environ Sci Techno 32: 297-336.

16. Akhtar MM, Zhonghua T (2014) Municipal Solid Waste and Its Relation with Groundwater Contamination in Lahore, Pakistan. Res J Appl Sci Engg Tech 7: 1551-1560.

17. Öman CB, Junestedt C (2008) Chemical characterization of landfill leachates - 400 parameters and compounds. Waste Manage 28: 1876-1891.

18. Kulikowska D, Klimiuk E (2008) The Effect of Landfill Age on Municipal Leachate Composition. Bioresour Technol 99: 5981-5985. 